\title{
Desentranhado de Schreber ${ }^{1}$
}

\author{
Modesto Carone
}

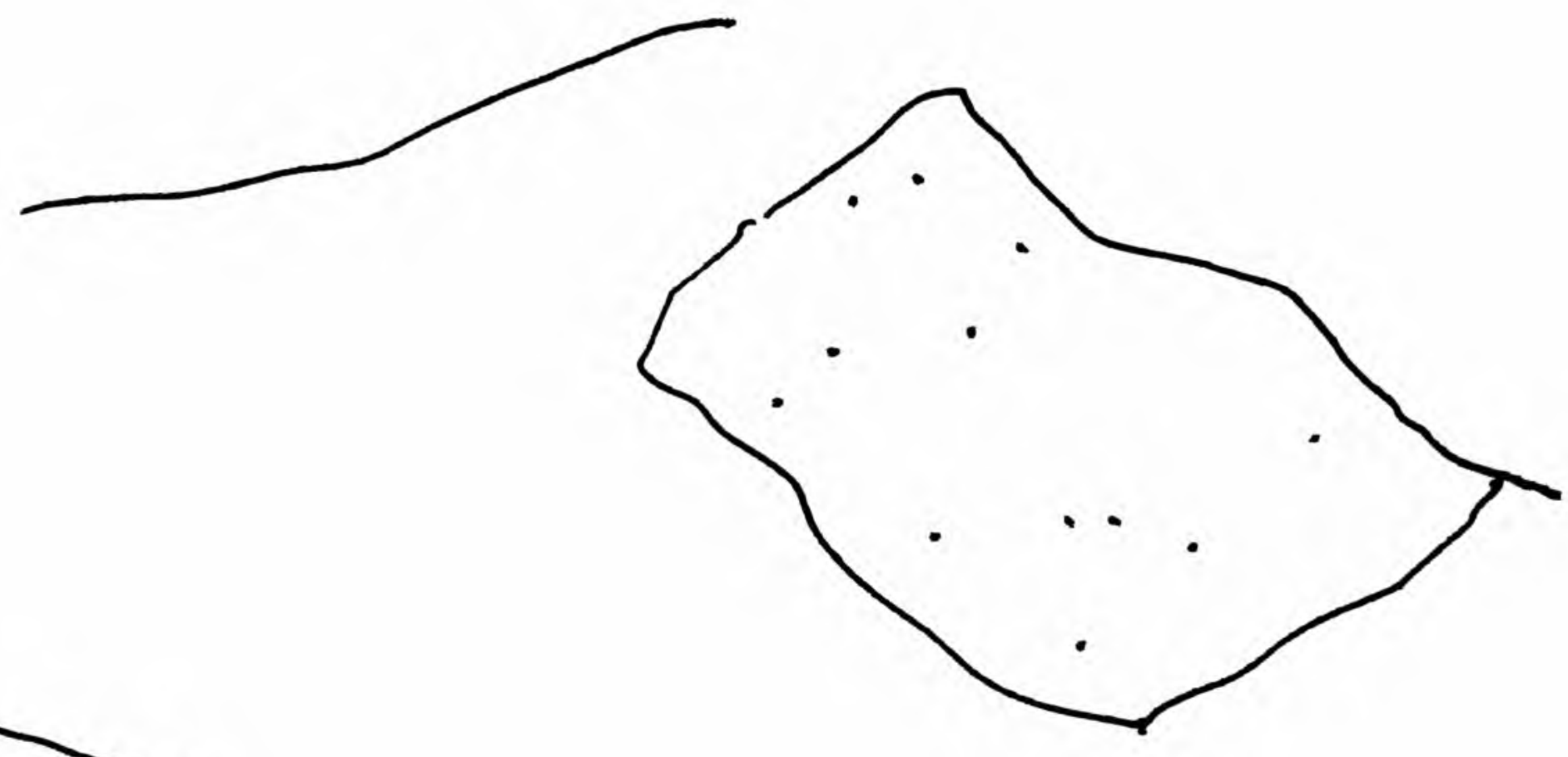


Contar é o método mais eficiente que consegui desenvolver para impedir a manifestação dos urros; tanto que eles emudecem assim que o cortejo de números parte do cérebro para a boca. O avanço é decisivo em primeiro lugar porque desmente a versão de que sou um idiota incapaz de pensar; em segundo porque é desse modo que concilio o sono. Na verdade só quem emite uma sucessão de urros na hora de dormir sabe a que ponto o fenômeno é inoportuno. No meu caso ele muitas vezes me faz pular da cama, pôr os chinelos, girar nos calcanhares e cumprir uma tarefa suficientemente clara para provar que sou um ser racional — por exemplo enumerar os reis de França ou fazer e desfazer nós consecutivos nas quatro pontas de um lenço.

Algo semelhante ocorre quando visito lugares públicos na companhia de pessoas educadas. Aí a intromissão dos urros nas pausas de conversa é fatal a menos que eu permaneça contando sem parar. Com a providência o máximo que se ouve são ruídos que os interlocutores interpretam como tosse, pigarros e bocejos desastrados, ou seja: nada que se preste a um escândalo.

Em compensação fico eufórico quando passeio pelo campo: são momentos bem-aventurados em que simplesmente deixo os urros virem a mim. Nem preciso dizer que eles invadem o meu corpo como uma torrente de água enquanto o espírito se rejubila atravessado por incontáveis gritos e clarões.

É evidente que se alguém estiver observando a cena de fora pensará que tem diante de si um louco; por isso não é de hoje a conviç̧ão de que basta uma palavra para que eu suprima os urros e demonstre minha completa lucidez mental.

\footnotetext{
I Daniel Paul Schreber ( 1842 - I 9 I I ) é autor das notáveis Memórias de um doente dos nervos e o único paciente-texto de Freud. Juiz-presidente de uma corte de apelação judicial da Alemanha, Schreber passou grande parte da vida em sanatórios. Marilene Carone traduziu sua obra para o português (Editora Paz e Terra, 1995).
} 